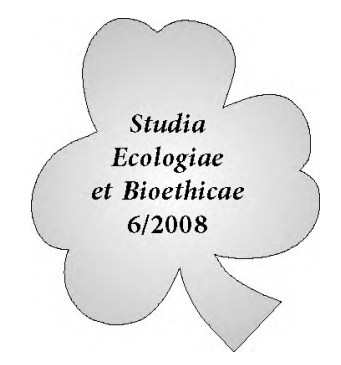

\title{
Od ruchu protestu do partii władzy. Rozwój Zielonych w Niemczech
}

Partie Zielonych są obecne w europejskich systemach partyjnych już od ćwierć wieku i w wielu $\mathrm{z}$ nich wypracowały sobie silną pozycję. Zieloni stali się stałym elementem sceny politycznej. Po utracie swojej reprezentacji w parlamencie (Niemcy 1990, Szwecja 1991) potrafili nie tylko ponownie uzyskać mandaty, ale także wejść do koalicji rządzącej, a nawet utrzymać się w niej więcej niż jedną kadencję.

Początki są związane z ruchami sprzeciwu wobec zanieczyszczenia środowiska, prowadzenia wojen i łamania praw człowieka. Ideologicznych korzeni zielonych należy poszukiwać w powstałym w latach 60-tych XX wieku ruchu społeczno-politycznym kontestującym konsumpcjonizm i autorytarne tendencje państwa. Przeszedł on do historii pod nazwą Nowa Lewica, i stał się nowym nurtem politycznym obok konserwatyzmu liberalizmu i socjalizmu. Przekształceniu tych wszystkich inicjatyw w partie polityczne sprzyjał korzystny klimat społeczny lat 70. i 80., ukształtowany przez troskę o wymierające lasy, obawę przed odpadami z elektrowni jądrowych i wojną nuklearną.

Chociaż Zieloni w Niemczech nie byli pierwszymi w Europie, którzy założyli partię i wprowadzili ją do parlamentu, gdyż wcześniej dokonali tego Belgowie, to jednak oni stali się przykładem stymulującym powstawanie zielonych partii w Europie Zachodniej, a ich siła oddziaływania objęła również Europę Wschodnią. Powstanie Partii Zielonych (Die Grüne Partei) w Niemczech wywołało zaniepokojenie wśród wielu obserwatorów niemieckiej sceny politycznej i życia społecznego. Stabilność i przewidywalność państwa niemieckiego po wojnie kontrastowała z rozchwianą sytuacją w Republice Weimarskiej. Co więcej w latach 70. mówiło się nawet o modelu niemieckim (Modell Deutschland), jako przykładzie sukcesu ekonomicznego i politycznego, na którym mogły by się wzorować inne demokracje. Cud gospodarczy (Wirtschaftswunder) doprowadził do marginalizacji sił radykalnych zarówno z lewej jak i z prawej strony, kształtując centrypetalny system partyjny. Pojawienie się Partii Zielonych w Bundestagu rozbudziło obawę, ze zieloni jako ruch protestu podkopią stabilną demokrację przez blokadę instytucji parlamentu, co w rezultacie miało doprowadzić do powtórki z Weimaru, 
czyli do obalenia demokracji i wprowadzenia dyktatury. Dlatego wielu krytyków zaatakowało Zielonych jako agentów totalitaryzmu.

\section{Korzenie ideologiczne i społeczne}

Partie w swoich założeniach programowych nawiązują do pewnych doktryn politycznych i poglądów filozoficznych. Partie komunistyczne opierają się na „Manifeście komunistycznym” i ideologii marksistowskiej. Podstawą, do której nawiązują partie chadeckie i bliskie im chłopskie jest społeczna nauka kościoła. Partie liberalne odwołują się do klasycznego liberalizmu ekonomicznego Szkoły Austriackiej. Natomiast za główną ideologię Zielonych uważana jest Nowa Lewica.

$\mathrm{Na}$ przełomie lat 50. i 60. XX wieku pojawił się w USA proces społeczny określany jako kontrkultura, bunt młodych albo rewolta studencka. Bunt pojawił się w południowych stanach USA, stopniowo rósł w siłę i rozprzestrzeniał się na cały kraj, a następnie dotarł do Europy Zachodniej, Japonii obejmując rozwinięte państwa kapitalistyczne. Ruchowi towarzyszyły rozważania filozoficzne: Herberta Marcuse, 凶eodora Dorno, Maxa Horkheima, \oma Haydena oraz przemyślenia kontestujących studentów jak Rudi Dutschke, Daniel CohnBendit. 囚en szeroki ruch został określony mianem Nowej Lewicy. Jak pisał Marcuse $w$ „Eros i cywilizacja” Nowa Lewica nie była ortodoksyjnie marksistowska. Odrzucała wszelkie ideologie łącznie z socjalistyczną, którą była rozczarowana, nie ograniczała się do kategorii klasowych, obejmując również intelektualistów i młodzież. Marcuse podkreślał również, że jej rzecznikami nie byli działacze polityczni, ale poeci i pisarze ${ }^{1}$.

Za początek buntu uważa się walkę ludności murzyńskiej o pełne prawa obywatelskie i sprzeciw wobec segregacji rasowej. Przywódcą został pastor Martin Luther King, kierujący pierwszą akcją protestacyjną w 1956 r. Obok walki Murzynów o swoje prawa pojawił się ruch przeciwko imperialistycznej polityce USA oraz wojnie w Wietnamie, organizujący masowe demonstracje pokojowe. Powstało wiele organizacji zrzeszających przeciwników wojny oraz weteranów Wietnamu. Początkowo zarówno bunt ludności murzyńskiej, jak i ruch pacyfistyczny, stosował pokojowe, wielotysięczne marsze. Kiedy państwo rozpoczęło stanowczą walkę z tzw. „rewolucją siedzącą" (nazwa od metody protestu jaką było okupowanie miejsc publicznych) buntująca się młodzież zaczęła prowadzić rewolucję wojującą, a trzecim duchowym przywódcą pokolenia obok Karola Marksa i Herberta Marcusego został Mao Zedong. Stąd na transparentach hasło „3 x M”

Por. K. Karolczak, Od chadecji do syjonizmu. Szkice o myśli politycznej XX wieku, Warszawa 1996, s. 44. 
gdzie Marks miał być Bogiem, Marcuse Prorokiem, a Mao mieczem nowej religii. Pojawily się zorganizowane grupy stosujące przemoc jak Black Panthers. W tym czasie szeroko rozwinęła się kontrkultura jako reakcja pokolenia na wzorce polityczne, społeczne i kulturowe, które w rozumieniu kontestującej młodzieży zniewalają ludzi, odbierając umiejętność krytycznego myślenia. Przejawem kontrkultury były nowe, często skandalizujące formy wyrazu artystycznego w literaturze, muzyce i filmie. Również w sferze obyczajowości dokonały się rewolucyjne przemiany, których symbolem stali się hipisi ${ }^{2}$.

Choć Nowa Lewica negowała jednocześnie imperialny kapitalizm i realny socjalizm, to jednak ideologicznie bliższa była marksistowskiej krytyce kapitalizmu. Intelektualiści poddali bardzo ostrej krytyce system amerykański za militaryzm i rasizm, skrajny indywidualizm i jednocześnie mówili o jego reformowaniu w oparciu o wartości lewicowe. Dla ideologów Nowej Lewicy podstawowym zadaniem ludzkości jest realizacja hasła „wolność, równość, braterstwo”, ich zdaniem w państwie kapitalistycznym jest to niemożliwe. Konsekwencją tego wniosku był postulat powrotu do działań rewolucyjnych. Marscuse doszedł do wniosku, że skoro klasa robotnicza jest silna jak nigdy dotąd a mimo to nie jest zdolna do rewolucji to stała się siła konserwatywną. Dlatego też najbardziej rewolucyjną siłą jest tzw. salariat, czyli głównie inteligencja, szeroka grupa nie powstająca w wyniku posiadania lub nie środków produkcji, ale poprzez sprzedaż swojej pracy. Đa grupa stanowi w krajach rozwiniętych stan trzeci i ma największy udział w tworzeniu dochodu narodowego, a jednocześnie najmniejszy w jego podziale. Jednak rewolucja nie miała dokonać się z użyciem przemocy, ale polegać na wyzwoleniu człowieka od przymusu dzięki popędom i instynktom thumionym przez cywilizację. Đylko niektórzy działacze będąc pod wpływem tradycyjnych idei rewolucyjnych nawoływali do chwycenia za broń i to właśnie oni kierowali rewoltą studencką $1968^{3}$.

Wydarzenia jakie miały miejsce w USA odbiły się szerokim echem również w Republice Federalnej Niemiec. Ruch studencki jaki się rozwinął miał swoje specyficzne podłoże. Studenci uważali niemieckie społeczeństwo za skostniałe, drobnomieszczańskie, niezdolne do bezwzględnego rozliczenia się z nazistowską przeszłością, nastawione tylko na rozwój gospodarczy. Kiedy w 1966 r. powstała wielka koalicja dwóch partii masowych CDU/CSU oraz SPD, powszechne stało się twierdzenie, że Niemcy są demokracją fasadową, ponieważ nie ma realnej opozycji (FDP miało tylko 49 mandatów). Kiedy rząd wielkiej koalicji zaczął rozważać wprowadzenie większościowego systemu wyborczego, aby ograniczyć scenę polityczną do dwóch partii, doszło do powstania opozycji pozaparlamentarnej (Ausserparamentarischen Opposition, APO). Stanowcza krytyka

\footnotetext{
Por. ibidem, s. 45-48.

Por. ibidem, s. $48-50$.
} 
APO dotyczyła dużych partii politycznych, systemu parlamentarnego, małej demokratyzacji Niemiec, a także wojny w Wietnamie i wykorzystywania państw \rzeciego Świata. Do tego doszedł sprzeciw wobec planowanej ustawie o stanie wyjątkowym, przewidującej możliwość ograniczenia praw w celu zapewnienia sprawności państwa w sytuacji kryzysowej. Ustawa została odebrana jako próba ograniczenia demokracji ${ }^{4}$.

W 1967 r. ukazała się książka H. Marcuse „Człowiek jednowymiarowy”, ukazująca zniewolenie czlowieka w społeczeństwie kapitalistycznym. Została ona uznana za manifest programowy buntu studenckiego. Duży wpływ miała także „szkoła frankfurcka" i myśl socjologiczna Maksa Horkheima (krytyczna teoria społeczeństwa) oraz Theodora Adorno, którego teoria osobowości autorytarnej stanowiła podstawę krytyki społeczeństwa. Jednocześnie w analizie współczesnego układu społecznego ruch studencki wracał do myśli Karola Marksa. Najważniejszą organizacją rewolty studenckiej był Socjalistyczny Niemiecki Związek Studencki (Socialistische Deutsche Studentenbund SDS) założony w 1946 r. jako przybudówka SPD. Jednak socjaldemokraci zerwali związki z SDS z powodu nieakceptowania reformatorskiego programu z Godesberger, $w$ którym zrezygnowano z marksistowskiej walki klas jako myśli przewodniej. W czasie buntu studenckiego SDS przeżyło nagły wzrost liczby członków ${ }^{5}$.

W trakcie licznych protestów dochodziło do ostrych starć z policją. W trakcie jednego $\mathrm{z}$ nich policjant zastrzelił studenta. Po tym wydarzeniu dziennik Bild wystąpił z krytyką działań studentów, kierując przeciw nim opinię publiczną. 11. kwietnia 1968 r. ciężko postrzelono neomarksistę, orędownika i przywódcę ruchu studenckiego Rudiego Dutschke. Studenci za winne tego wydarzenia uznali wydawnictwo Springer i rozpoczęli blokady drukarni w celu utrudnienia rozwożenia dziennika Bild, czemu również towarzyszyły starcia z policją. \o był szczytowy moment buntu, który szybko tracił poparcie. Po nieudanej próbie zorganizowania strajku generalnego razem ze związkami zawodowymi i po utworzeniu socjalno-liberalnej koalicji z Willy Brandtem jako kanclerzem, związek SDS rozwiązał się. Byli aktywiści przeszli różne drogi. Najwięcej z nich ukończyło studia, rozpoczęło tzw. „długi marsz przez instytucje” i zrobiło karierę w nauce, gospodarce oraz polityce. Mniejszość zorganizowała różne organizacje komunistyczne (K-Gruppen) jak Komunistyczny Związek Niemiec Zachodnich (Kommunistische Bund Westdeutschlands $K B W$ ). Nieliczni przeszli do podziemia, aby kontynuować walkę metodami z użyciem przemocy i utworzyli Frakcję Czerwonej Armii (Rote Armee Fraktion RAF) radykalną organizację terrorystyczną, która w 1977 r. przez serię porwań i zabójstw doprowadziła do kryzysu zwanego „niemiecką jesienią"6.

\footnotetext{
Por. M. Klein, J. Falter, Der lange Weg der Grïnen, Monachium 2003, s. 16.

Por. ibidem, s. 17.

6 Por. ibidem, s. 19.
} 
Drugim nurtem, z którego wywodzi się Partia Zielonych to liczne ruchy obywatelskie, będące wyrazem przemian jakie dokonały się w latach 60 . w wysokorozwiniętych społeczeństwach przemysłowych. Daniel Bell, ukuł termin „społeczeństwa postindustrialnego", mający oznaczać właśnie zmierzch przemysłu i dominację usług oraz znacznie większą niż dotychczas rolę wiedzy naukowej i informacji, porzucenie standaryzacji procesów wytwórczych i zróżnicowanie stylów życia, zanik postaw egoistycznych na rzecz dowartościowania interesu wspólnotowego i współpracy, wykorzenienie przy pomocy technologii niemal wszystkich bolączek poprzednich epok ${ }^{7}$. W latach 70. w wyniku wzrostu gospodarczego, rozwoju edukacji, rozluźnienia więzi społecznych doszło do zmian wartości z materialistycznych jak praca na postmaterialistyczne jak samorealizacja.

Nowe inicjatywy społeczne poruszały tematy ochrony środowiska, pokoju na świecie oraz emancypacji kobiet. W literaturze niemieckiej zostały określone jako „nowe ruchy społeczne” (Neue Sozialen Bewegungen). Pojęcie to oznacza zbiorowego aktora $\mathrm{z}$ niskim stopniem organizacji instytucjonalnej, bez formalnego czlonkowska i hierarchicznej struktury. Jedność utrzymuje się dzięki silnej identyfikacji wewnętrznej i mocnemu odcięciu się od zewnętrznych przeciwników. W celu realizacji żądań ruchy posługiwały się niekonwencjonalnymi metodami skierowanymi przeciw elitom władzy, stosowanymi wcześniej przez bunt studencki, jak legalne i nielegalne demonstracje, rozdawanie ulotek, blokowanie placów budowy i dróg. Nowym ruchom społecznym udało się uzyskać większe poparcie i zmobilizować więcej działaczy niż bunt studencki ${ }^{8}$.

Wydarzenia jakie miały miejsce w latach 60 . ukształtowały politycznie całą generację, która odegrała znaczącą rolę w tworzeniu Partii Zielonych. Ruch ochrony środowiska był reakcją na negatywne dla kondycji Ziemi skutki wywołane nieograniczonym wzrostem i niezrównoważoną polityką gospodarczą, o czym uświadomił raport Klubu Rzymskiego z 1972 r. Ruch pokojowy był wyrazem zaniepokojenia, spowodowanym niepewnością i niestabilnością dwubiegunowego świata. Z kolei ruch feministyczny, wyrastający bezpośrednio z buntu studenckiego domagał się nowej regulacji stosunków społecznych, faktycznego równouprawnienia kobiet. 凶e żądania zostały bezpośrednio wpisane po raz pierwszy do programu Partii Zielonych.

\section{Rozwój historyczny}

Partia Zielonych była pierwszą nową partią w niemieckim systemie partyjnym od lat 50 . Przez długi czas funkcjonował bardzo stabilny system dwu

Por. D. BeLl Kulturowe sprzeczności kapitalizmu, Warszawa 1998.

8 Por. M. Klein, J. Falter, Der lange Weg..., op. cit., s. 20. 
i półpartyjny, w którym FDP jako zdolne do zawierania koalicji zarówno z CDU/ CSU jak i z SPD pełniło funkcję języczka u wagi. W latach 1949-1998 FDP nie było w rządzie tylko dwukrotnie, w latach 1957-1961, gdy CDU/CSU rządziło samodzielnie oraz w okresie 1966-1969, kiedy miała miejsce tzw. wielka koalicja chadeków i socjaldemokratów. Pojawienie się Partii Zielonych doprowadziło do przekształcenia systemu partyjnego w system dwublokowy. Założenie partii i rozwój każdej nowej partii po 1949 roku dokonywało się zawsze w pierwszej kolejności na poziomie landów. Wiąże się to ze specyfiką niemieckiego ustroju politycznego, który jest ustrojem federalnym. Droga każdej partii do Bundestagu wiedzie poprzez sukcesy wyborcze w poszczególnych krajach związkowych.

Zieloni swój początek mają w Dolnej Saksonii, gdzie rząd landu od połowy lat 70. planował budowę składowiska odpadów atomowych w okolicach miejscowości Gorleben. W roku 1977 założono ugrupowanie pod nazwą „Zielona Lista Ochrony Środowiska" (Grüne Liste Umweltschutz), które w wyborach do Landtagu osiągnęło 3,9 \% głosów i choć nie przekroczyło wymaganego pięcioprocentowego progu wyborczego to zwróciło uwagę na opinii publicznej ${ }^{9}$. W tym czasie na obszarze całej Republiki Federalnej Niemiec, powstawały różnego rodzaju podobne inicjatywy oraz związki alternatywne i brały udział w wyborach do krajów związkowych. Pierwszym, który odniósł sukces wyborczy była „Zielona Lista Bremy” (Bremer Grüne Liste) zdobywając w lutym 1979 w wyborach do Landtagu 5,1\% głosów ${ }^{10}$. Kolejnym landem, w którym „zielone” stronnictwo odniosło sukces była Badenia Wirtembergia. W tym czasie pojawiły się także próby tworzenia ugrupowania na poziomie związku. Do pierwszych wyborów do Europarlamentu „zielone” inicjatywy wystartowały pod nazwą Inne Zjednoczenie Polityczne - Zieloni (Sonstige Politische Vereinigun-Die Grüne) i osiągnęły w skali kraju 3,2 \%, a także otrzymały zwrot nakładów na kampanię w wysokości 4,5 miliona marek. Suma ta pozwoliła na przygotowanie się do nadchodzących wyborów krajowych ${ }^{11}$.

Do zjednoczenia licznych ugrupowań i list wyborczych z całego kraju doszło ostatecznie 13. stycznia 1980, kiedy to na zjeździe w Karlsruhe założono Partię Zielonych (Die Grünen). Jednakże pierwsze wybory do Bundestagu były dla nowopowstałej partii wielkim rozczarowaniem. Zieloni w wyborach z października 1980 r. otrzymali tylko 1,5\% tzw. drugich głosów ${ }^{12}$. Wybory do landtagów w 1982 r. byly znakiem postępującej konsolidacji partii, ponieważ udało jej się dostać do parlamentów w Hamburgu, Hesji i w Dolnej Saksonii, gdzie uzyskała lepszy wy-

9 Por. K. Niclauß, Das Parteisystem der Bundesrepublik Deutschland, Monachium 1995, s. 91.

10 Brema jednym $\mathrm{z}$ trzech, obok Hamburgu i Berlina, miastem na prawach landu.

11 Por. Ibidem, s. 92.

12 W niemieckim mieszanym systemie wyborczym każdy wyborca oddaje dwa głosy; pierwszy na kandydatów w jednomandatowych okręgach wyborczych; drugi na listy partyjne. Por. W. Rudzio, Das politische system der Bundesrepublik Deutschland, Opladen 2003, s. 197 - 198. 
nik niż FDP, stając się trzecią siłą w landtagu. Przed wyborami do Bundestagu w 1983 r. Zieloni mieli swoją reprezentację w sześciu parlamentach związkowych i dlatego długo oczekiwane wejście do parlamentu krajowego, dzięki uzyskaniu 5,6 \% głosów, nie było zaskoczeniem. Niemniej jednak było to ważne wydarzenie w bardzo stabilnym systemie politycznym Niemiec, gdzie w latach 1961-1983 miedzy 95 a $99 \%$ głosów wyborców zostało oddanych na trzy partie zasiadające w Bundestagu. Cztery lata później partia powiększyła swą reprezentację w Bonn zdobywając 8,3 \% głosów co przełożyło się na 42. parlamentarzystów. $\mathrm{Z}$ początkiem procesu zjednoczenia Partia Zielonych była reprezentowana we wszystkich landtagach za wyjątkiem Szlezwik Holsztyn i Kraju Saary ${ }^{13}$.

W przypadku Zielonych proces zjednoczenia przebiegał znacznie trudniej niż pozostałym partiom zachodnioniemieckim. Po fazie konsolidacji na terenie landów zachodnich pojawiła się konieczność tworzenia struktur w nowych krajach związkowych. Partnerem po tej stronie stały się organizacje wschodnioniemieckiego ruchu obywatelskiego: Nowe Forum (Neue Forum), Demokracja Qeraz (Demikratie Jetzt) oraz Inicjatywa Pokój i Prawa Człowieka (Initiative für Frieden und Menschenrechte), które w lutym 1990 r. połączyły się w Związek 90 (Bündnis 90). Drugim partnerem była utworzona już w listopadzie $1989 \mathrm{r}$. Partia Zielonych. Oba ugrupowania wystartowały 14. października $1990 \mathrm{w}$ wyborach do landtagów pięciu nowych krajów związkowych, odnosząc sukces tam gdzie poszły razem (\uryngia, Saksonia, Saksonia Anhalt), a porażkę gdzie wystawiły oddzielne listy (Brandenburgia, Meklemburgia, Pomorze Wschodnie) ${ }^{14}$.

Tabela 1. Rozwój Partii Zielonych na poziomie krajów zwiazkowych

\begin{tabular}{|l|c|c|}
\hline Kraj związkowy & Rok założenia & Obecność w parlamencie krajowym od roku: \\
\hline Badenia-Wirtembergia & 1979 & 1980 \\
\hline Bawaria & 1979 & 1986 \\
\hline Berlin & 1978 & 1981 \\
\hline Brema & 1979 & 1979 \\
\hline Hamburg & 1978 & 1982 \\
\hline Hesja & 1980 & 1982 \\
\hline Saksonia Dolna & 1977 & 1982 \\
\hline Nadrenia Pólnocna-Westfalia & 1978 & 1990 \\
\hline Nadrenia Palatynat & 1978 & 1987 \\
\hline Saara & 1979 & 1994 \\
\hline Szlezwik-Holsztyn & 1979 & 1996 \\
\hline
\end{tabular}

Źródło: F. Müller-Rommel, 冈. Poguntke, Die Grünen, w: A. Mintzel, H. Oberreuter, Parteien in der Bundesrepublik Deutschland, Opladen 1992, s. 326

13 Por. K. Niclauß, Das Parteisystem..., op. cit., s. 93.

14 Por. F. Müller-Rommel, D. PGuntke, Die Grïnen, w: A. Mintzel, H. Oberreuter (red.), Parteien in der Bundesrepublik Deutschland, Bonn 1992, s. 330-331. 
Przed pierwszymi w zjednoczonych Niemczech wyborami do Bundestagu z różnych przyczyn nie doszło jednak do połączenia Zielonych ze wschodniej i zachodniej części kraju. Zachodnioniemieccy Zieloni wystąpili do Ørybunału Konstytucyjnego (Bundesverfassungsgericht) o zastosowanie pięcioprocentowego progu wyborczego oddzielnie dla okręgu zachodnio i wschodnioniemieckiego, chcąc w ten sposób uchronić się przed ewentualną groźbą nieprzekroczenia tego progu ze względu na niepewną i niestabilną sytuację wschodnioniemieckich Zielonych. W wyborach z 2. grudnia 1990 Zieloni w byłej Niemieckiej Republice Demokratycznej uzyskali 6,1\% głosów i 8 mandatów, a na terenie byłej Republiki Zachodnioniemieckiej 4,8 \% nie wprowadzając żadnego ze swych kandydatów do parlamentu. 区ym samym Zieloni z zachodu ślepo ufający badaniom opinii publicznej stali się ofiarami własnego wyrafinowania, ponieważ w przypadku zastosowania jednego progu dla całego kraju otrzymaliby $5,05 \%{ }^{15}$.

Po długim okresie żmudnych rozmów dotyczących kwestii politycznych i organizacyjnych jak choćby nazwa partii, obie strony doszły do porozumienia i w styczniu 1993 na konwencji w Hanowerze podpisano traktat zjednoczeniowy, ustanawiający partię Związek 90/Zieloni (Bündnis90/Die Grünen). Na tej fuzji skorzystali głównie zachodnioniemieccy Zieloni, co było widoczne w serii porażek jaką odnieśli wschodnioniemieccy koledzy w wyborach do landtagów w 1994 r., jedynie w Saksonii Anhalt udało się przekroczyć 5 \%.Wybory do Bundestagu z listopada 1994, w których partia zdobyła 7,3 \%, okazały się sukcesem. Pozwalającym na wprowadzenie 49 parlamentarzystów i stanie się trzecią siłą Bundestagu. W następnych wyborach do landtagów partia odniosła kolejne dobre wyniki i stała się koalicjantem SPD w czterech krajach związkowych, w których powstały tzw. czerwono-zielone rządy. Sytuacja partii przed kolejnymi wyborami do Bundestagu przedstawiała się korzystnie. Na podstawie pomyślnych badań opinii publicznej Zieloni mieli nadzieję, że uda się poprawić poprzedni wynik. Partia wystąpiła w kampanii z bardzo ostrą krytyką rządów „wiecznego kanclerza" Helmuta Kohla, które w powszechnej opinii jawiły się jako wyczerpane i niezdolne do przeprowadzenia reform. Partia w powszechnej opinii społecznej stała się potencjalnym partnerem rządowym dla SPD, które pewnie kroczyło po zwycięstwo. Niefortunna okazała się konwencja wyborcza w Magdeburgu, gdzie ustalając program wyborczy postulowano podwyższenie cen benzyny do pięciu marek za litr. W krótkim okresie czasu partia straciła nie tylko dobrą pozycję w sondażach ale także przez lata ciężko wypracowane zaufanie Niemców. Powrócił obraz Zielonych jako nieprzewidywalnej partii chaosu. Na krótko przed wyborami pojawiła się obawa, że partia może nie być w stanie przekroczyć progu wyborczego. Ostatecznie jednak w wyborach udało się zdobyć poparcie 6,7 \% poparcia głównie dzięki dobrej kampanii kandydata na kanclerza J. Fischera, który w autobusie wyborczym przemierzył cały kraj zabiegając o głosy poparcia. Zwycięzcą tych wyborów stało się SPD, które po 16. latach odsunęło od rządów 
koalicję chadeków z CDU/CSU i liberałów z FDP. 27. października 1998 Gerhard Schröder został nowym kanclerzem Niemiec, a J. Fischer wicekanclerzem i ministrem spraw zagranicznych. W rządzie znalazło się jeszcze dwóch ministrów z Sojuszu90/Zieloni Jürgen \rittin objął Ministerstwo Środowiska, a Andrea Fischer Ministerstwo Zdrowia. W ten sposób po 18. latach od powstania, czyli po osiągnięciu politycznej dojrzałości, udało się partii dojść do sterów władzy ${ }^{16}$.

Początki funkcjonowania w rządzie były trudne. Ponieważ większość społeczeństwa była za zmianą rządów, ale niekoniecznie za udziałem w nich Partii Zielonych, uważanej przez większość społeczeństwa za niezdolną do racjonalnego rządzenia. W pierwszym okresie udziału w rządzie Zieloni pozostawali w politycznej defensywie, jedynie asystując socjaldemokratom. Przyczyną tej sytuacji była rozbieżność między oczekiwaniami zwolenników partii, a jej faktyczną pozycją w rządzie. Dobrym przykładem jest kwestia rezygnacji z energii atomowej. Rząd po negocjacjach z przemysłem energetycznym ustalił okres 35 . lat na stopniowe wycofywanie energii atomowej. Dla Zielonych był to ważny temat stanowiący jeden z głównych punktów ideologii. Ustalenia rządu w tej kwestii wywołały mieszane reakcje wśród zwolenników partii, wielu z nich uważało tą decyzję za korzystną dla lobby atomowego. Z biegiem czasu Partia Zielonych odnalazła się w nowej sytuacji zaczęła wychodzić z ciekawymi propozycjami ustaw dotyczącymi energii odnawialnej czy ubezpieczeń zdrowotnych. Po dwóch latach rządów koalicji bez wyraźnych sukcesów, zaczęło słabnąć poparcie społeczne dla kanclerza G. Schrödera, głównie z powodu niepowodzeń w walce z bezrobociem. Od tego momentu Zieloni zaczęli korzystać z kryzysu na czele SPD, dokonali też reformy struktury i przyjęli nowy program zasadniczy. \uż przed wyborami w sierpniu 2002 koalicja CDU/CSU i FDP, wyprzedzała koalicję „czerwono-zieloną w badaniach opinii publicznej. Jednak koalicji rządzącej udało się obronić władzę dzięki umiejętnemu wykorzystaniu powodzi stulecia we wschodnich landach i sprzeciwu wobec wojny w Iraku. SPD uzyskało mniej głosów niż w poprzednich wyborach co zostało zrekompensowane przez 8,6 \% (55 mandatów) Zielonych, ich najlepszy wynik w wyborach do Bundestagu ${ }^{17}$.

Druga „czerwono-zielona” koalicja za główny cel postawiła reformy społeczne. W 2003 przyjęto Agendę 2010, program obejmujący reformy systemu socjalnego i rynku pracy, nawiązujący do Strategii Lizbońskiej. Uchwalono kilka ustaw wprowadzających cięcia w wydatkach socjalnych np. pakiet Hartz IV, który wywołał masowe protesty związków zawodowych. Podejmowane działania nie przynosiły jednak oczekiwanych rezultatów notowania partii rządzących spadały. Po przegranych przez SPD wyborach w jej mateczniku w Nadrenii Północnej Westfalii kanclerz Schröder zgłosił wniosek o wotum zaufania, którego nie otrzymał. W przedterminowych wyborach z sierpnia 2005 r. Zieloni uzyskali $8,1 \%$ głosów, czyli niewiele mniej niż w poprzednich wyborach, jednak tym razem było to zbyt mało, aby utrzymać się koalicję. Partia Zielonych stała się trzecią 
co do wielkości partią opozycyjną po FDP i powracającą do Bundestagu Partią Lewicową (Die Linkspartei ${ }^{18}$ ).

\section{Jedność w różnorodności}

Cechą partii politycznej jest jej wewnętrzne zróżnicowanie. Partie nie są monolitem jeśli wziąć pod uwagę zarówno ich członków jak i wyborców. Sami Zieloni mówią o sobie, że stanowią „jedność w różnorodności”. Zjawisko to było szczególnie wyraźne w początkowej fazie konsolidacji różnorodnych inicjatyw obywatelskich w jeden komitet wyborczy a następnie w partię. Spoiwem łączącym wszystkie nurty była ochrona środowiska i dążenie do stworzenia alternatywy dla tradycyjnych partii. W obrębie ruchu ekologicznego można wyróżnić trzy zasadnicze nurty: konserwatywny, umiarkowany oraz radykalny.

Skrzydło konserwatywne za punkt ciężkości przybrało kwestie ekologiczne natomiast poglądy na sprawy społeczne i ideologiczne pozostawały na drugim planie i nie odbiegały zasadniczo od reprezentowanych przez tradycyjne partie. Reprezentowane było ono przez Zieloną Akcję Przyszłość (Grüne Aktion Zukunft) byłego deputowanego CDU Herberta Grula i ekorolnika Baldura Springmana. \o ugrupowanie opuściło Zielonych już w 1980 r. zakładając Partię Ekologiczno Demokratyczną (Ökologisch Demokratische Partei). Podczas zjazdu programowego w Karlsruhe przedstawiciel Badenii Wirtembergii powiedział: „Nie chcemy partii, arbuza, z zewnątrz zielonej wewnątrz czerwonej” odcinając się od poglądów radykalnych. ${ }^{19}$.

Nurt radykalny cechował się daleko idącą skrajnością poglądów, nie tylko w kwestiach ekologicznych ale także społecznych i własnościowych. Wywodził się m. in. z Komunistycznej Partii Niemiec zdelegalizowanej wyrokiem Związkowego \rybunału Konstytucyjnego z 1956 r. Opcję radykalną cechowało szerokie spektrum organizacji ją tworzących: anarchistyczne, maoistowskie, radykalno-demokratyczne, a także wywodzące się z protestów studenckich organizacje na rzecz $\nabla$ rzeciego Świata i mniejszości seksualnych. Do najpopularniejszych „kolorowych” ugrupowań zaliczały się Alternatywna Lista (Alternative Liste) oraz Kolorowa Lista Brońcie się (Bunte Liste Wehrt Euch) ${ }^{20}$.

Opcja umiarkowana mająca największy wpływ na powstawanie i kształtowa-

15 Por ibidem, s. 332.

16 Por. H. KLEINERT, Die Grünen in Deutschland, w: Heinrich-Böll-Stiftung (wyd), Die Grünen in Europa. Ein Handbuch, Munster 2004, s. 58-70.

17 Por. ibidem, s. $70-82$.

18 Partia polityczna powstała w 2005 z przekształcenia komunistycznej SED, a potem PDS, zrzesza głównie stęsknionych za NRD oraz ludzi kontentujących obecny system społeczny w Niemczech.

19 Por. H. Kleinert, Die Grünen in Deutschland..., op. cit., s. 60.

20 Por. K. Niclauß, Das Parteisystem..., op. cit., s. 93. 
nie partii poszukiwała koncepcji społecznej alternatywnej w stosunku do kapitalizmu i komunizmu zachowującej własność prywatną. W tym nurcie pojawiła się grupa tzw. Ekologicznych Libertarian (Ökolibertäre), domagających się „ekologicznej gospodarki rynkowej”, decentralizacji i ograniczenia funkcji państwa ${ }^{21}$.

W latach 80. dochodziło do licznych sporów między poszczególnymi nurtami, jak już wspomniano skrzydło konserwatywne wcześnie odłączyło się od partii w wyniku czego ukształtowały się dwa główne obozy tzw. fundamentalistów (Fundnis) oraz realistów (Realos). Również te frakcje nie były heterogenne. Hansa Joachim. Veen oraz Jürgen. Hoffman. wyróżnili w ich obrębie jeszcze mniejsze jednostki. Do fundamentalistów zaliczyli następujące nurty: Ekologiczni Socjaliści (Ökosocjalisten), Radykalni Ekolodzy (Radikalökologen) oraz Forum Lewicy (Linkes Forum). Natomiast wśród realistów wyróżnili: Zielony Przełom (Grüner Aufbruch), Ekologicznych Kapitalistów (Ökokapitalisten), Ekologicznych Libertarian $^{22}$. Głównym punktem różniącym dwa zasadnicze skrzydła była sprawa wspólpracy Partii Zielonych z SPD. W początkowym okresie dominowała frakcja radykalna, na czele której stała J. Dritfuhrt. Fundamentaliści angażowali się jeszcze w akcje protestacyjne, ortodoksyjnie trzymając się postanowieniu stworzenia partii całkowicie odmiennej od tradycyjnych. Wejście w koalicję z SPD uważali za zdradę ideałów. W drugiej połowie lat 80. stopniowo do głosu dochodzili bardziej pragmatycznie zorientowani realiści, którzy byli świadomi, że natychmiastowe osiągnięcie celów nie jest możliwe, dlatego konieczne jest formułowanie długookresowych strategii. Symbolicznym zwycięstwem realistów było zawiązanie pierwszej czerwono-zielonej koalicji rządowej w Landtagu Hesji w 1985 r., w której Joschka Fischer jako pierwszy Zielony został Ministrem Srodowiska. Dominacja fundamentalistów dobiegła kresu w 1988 r. wraz z odejściem J. Dritfurth z zarządu partii. Ostatecznie Radykalni Ekolodzy i Ekologiczni Socjaliści opuścili Partię Zielonych w $1992 \mathrm{r}^{23}$. Lata 90. to czas stopniowego zwiększania wpływów realistów, wiele osób o radykalnych poglądach wystąpiło z partii, czołową postacią frakcji i głównym adwersarzem J. Fischera został HansChristian Ströbele

\section{Ewolucja programowa}

Zdaniem niektórych politologów program żadnej partii, także Zielonych, nie odgrywa znaczącej roli, ponieważ potencjalni wyborcy nie chcą tracić czasu na zapoznanie się z nudnym zapisem, o wiele bardziej wolą dowiadywać się o sta-

21 Por. Ibidem, s. 95.

22 Por. H. J. Veen, J. Hoffmann, Die Grünen zu Beginn der neunziger Jahre, Bonn 1992, s. 59-71.

23 Por. H. J. Veen, J. Hoffmann, Die Grïnen zu Beginn..., op. cit., s. 55-72. 
nowisku partii z telewizji. Inni sprzeciwiają się takiemu myśleniu powołując się na badania: „Spośród ankietowanych w 2002 roku wyborców 50\% twierdziło, że podejmowało decyzję z uwagi na program partii, $20 \%$ głosujących, że ze względu na przywiązanie do danej partii, a 30\% kierowało się osobą głównego kandydata" ${ }^{24}$ Jeśli wierzyć tym deklaracjom, to znaczenie programu na wynik wyborów nie jest tak nieznaczne jak się sugeruje. Analizując zmiany program partii można powiedzieć dużo o jej rozwoju. \o jak długą drogę przeszła Partia Zielonych od momentu powstania, przez wejście do Bundestagu, aż po udział w koalicji rządowej bardzo wyraźnie ilustruje ewolucja programowa. Rozwój programowy partii obejmuje zmiany od pierwszego programu z 1980 r.(Saarbruecker Programm) przez umowę zjednoczeniową z 1993 po aktualny program „Przyszłość jest zielona" (Die Zukunft ist grun) z 2002 r.

Program założycielski powstał jako kompromis pomiędzy różnorodnymi ideologicznie ruchami. W preambule Zieloni określili się jako alternatywę dla tradycyjnych partii, a nawet jako „antypatię” (Anti-Parteien-Partei). Wyróżniono także cztery podstawowe wartości będące podstawą działań politycznych. Były to następujące filary: ekologia, sprawiedliwość socjalna, demokracja u podstaw i wolność od przemocy.

Na pierwszym miejscu jako spoiwo między wszystkimi ugrupowaniami stała ochrona środowiska. Podkreślano, że winę za katastrofalny stan środowiska naturalnego ponosi rabunkowa gospodarka kapitalistyczna. Aby rozwiązać ten problem proponowano ograniczenie wolnego rynku przez podporządkowanie celów gospodarczych ekologii. Dlatego za konieczne uważano przebudowę gałęzi przemysłu w taki sposób, aby samodzielne fabryki zaopatrywały bezpośrednio jak największy obszar. W ten sposób chciano ograniczyć zależność od rynku światowego oraz ograniczyć zużycie energii. Centrale znaczenie w ekologicznej koncepcji Zielonych miała natychmiastowa rezygnacja $z$ energii atomowej i zastąpienie jej źródłami alternatywnymi ${ }^{25}$.

Pod hasłem sprawiedliwości społecznej w pierwszym rzędzie rozumiano zmniejszenie różnic w dochodach. Cel ten chciano osiągnąć przez zwiększone obciążenia podatkowe dla najlepiej zarabiających. W tym miejscu zauważalny jest duży wpływ ekologicznych socjalistów (Ökosozialisten) domagających się nowych form własności społecznej ziemi, dóbr natury środków produkcji oraz banków. Z kolei w przypadku zasady wolności od przemocy uwidacznia się inspiracja inicjatyw na rzecz pokoju na świecie. Na ten filar składało się kilka radykalnych celów. Jednym z nich było żądanie natychmiastowego rozbrojenia armii, wystąpienie Niemiec z NA囚O i innych układów militarnych. Odrzucono wszelkie formy obrony militarnej domagając się rozwinię-

24 K. Bachmann, P. Buras., S. PŁóciennik, Republika bez gorsetu, Wrocław 2005, s. 44.

25 Por. F. MÜller-Rommel, 囚. PGuntke, Die Grünen..., op. cit., s. 335. 
cia społecznych strategii obrony, zakazu handlu posiadania i handlu bronią. W rozumieniu Zielonych, aby doprowadzić do pokoju w skali globalnej należy zwalczać biedę w krajach rrzeciego Świata, poprzez rozprowadzenie dóbr z bogatej północy na południe, oddłużenie państw i zmniejszenie ich uzależnienia od rynku światowego ${ }^{26}$.

Zieloni uważali, że tradycyjne partie są skostniałe przez co straciły kontakt ze społeczeństwem, dlatego dążyli od samego początku do stworzenia organizacji partyjnej nowego typu (Parteiorganisation neuen Typs), co znajduje swój wyraz w zasadzie demokracji u podstaw (Basisdemokratie). Jej główną myślą była ciągła kontrola instytucji, parlamentarzystów i osób sprawujących funkcje przez społeczeństwo. Aby urzeczywistnić tę ideę wprowadzono kilka zasad: rotację (wymiana deputowanych po połowie kadencji), mandat imperatywny (wykonywanie woli wyborców, zaleceń partii), otwartość posiedzeń partyjnych (umożliwienie wszystkim uczestnictwa w zebraniach), rozdzielność mandatu i urzędu (jedna osoba nie może jednocześnie sprawować dwóch funkcji ${ }^{27}$. Wiele $\mathrm{z}$ tych pryncypiów okazało się $\mathrm{w}$ praktyce trudne do urzeczywistnienia. Imperatywny mandat i rotacja od samego początku był kwestią sporną nie tylko $\mathrm{z}$ prawnego punktu widzenia (niemiecka ustawa zasadnicza $\mathrm{w}$ art. 38 . przewiduje wolny mandat), ale także trudne do realizacji w rzeczywistości (deputowani niechętnie rozstawali się z mandatem po dwóch latach). \e zasady miały dać możliwość każdemu członkowi sprawowania ważnej funkcji w partii oraz nie dopuścić do powstania kolejnej elity politycznej. Szybko okazało się, że w codziennej rzeczywistości społeczeństwo nie jest w stanie kontrolować swych reprezentantów, a oni pozostają w polityce na dłużej i nie chcą wracać do poprzednich zajęć. Demokracja u podstaw w rozumieniu Zielonych odniosła porażkę, ponieważ podejmowane najważniejszych decyzji przez wąską grupę działaczy jest wygodniejsze i sprawniejsze niż ciągła kontrola. W praktyce okazało się, że to Zieloni dostosowali się do zasad panujących w polityce, a nie na odwrót. ${ }^{28}$.

Zarówno mandat imperatywny jak i zasada rotacji zostały stopniowo odrzucane w poszczególnych landach i ostatecznie zaprzestano stosowania tych praktyk. Inną zasadą wprowadzoną przez Zielonych (a następnie przejętą przez inne partie) był parytet $50 \%$ miejsc dla kobiet na listach wyborczych, na stanowiskach partyjnych oraz $\mathrm{w}$ rządzie. Wiązało się to $\mathrm{z}$ dążeniem do faktycznego równouprawnienia mężczyzn i kobiet w społeczeństwie, gospodarce i polityce. Faktycznie reguła ta okazała się trudna do realizacji, gdyż udział kobiet wśród

26 Por. ibidem, s. 336.

27 Por. H. J. Veen, J. Hoffmann, Die Grünen zu Beginn der neunziber Jahre, Bonn 1992, s. 26.

28 Por. Ibidem, s. 33-40. 
członków wynosił około jednej trzeciej. Problem z brakiem odpowiedniej ilości kobiet kandydujących rozwiązano w ten sposób, że na miejscu pierwszym wystawiana jest kobieta na drugim mężczyzna na trzecim znowu kobieta itd. Okazuje się, iż ten model funkcjonuje do dziś, a w 1987 r. była nawet nadreprezentacja kobiet (57\%) we frakcji w Bundestagu. Od początku funkcjonowania Zielonych mają oni dwóch przewodniczących, mężczyznę i kobietę. Do chwili obecnej na stanowisku funkcjonowały: Patra Kelly, Anje Vollmer, Jutta Dritfurth, Renate Künast, Claudia Roth. Zasada parytetu została rozpowszechniona przez Zielonych i przejęta przez inne partie. W 1988 r. SPD wprowadziło kwotę $40 \%$ miejsc na listach i urzędach partyjnych dla kobiet ${ }^{29}$.

Zjednoczenie Niemiec i połączenie Zielonych z wschodnim partnerem Związek 90 spowodowało konieczność zdefiniowania na nowo wspólnych zasad jakimi miała się kierować powiększona partia. W umowie zjednoczeniowej wyznaczono cele partii w następującej kolejności: prawa człowieka, ekologia, demokracja, sprawiedliwość społeczna równouprawnienie kobiet i mężczyzn, wolność od przemocy. Znamienne jest tu postawienie na pierwszym miejscu praw człowieka przed ochroną środowiska, co wynika $z$ faktu, że nowa część partii powstała $z$ połączenia inicjatyw obywatelskich walczących przeciw dyktaturze SED. Pewnym novum było także wpisanie do zasad podstawowych równego traktowania kobiet i mężczyzn ${ }^{30}$. Zieloni z wschodnich landów wnieśli także inne spojrzenie na kwestię ekonomii i ekologii i wskazując że na zanieczyszczenie środowiska tak negatywnie samo jak gospodarka wolnorynkowa wpływa socjalistyczna gospodarka planowa.

Pierwszy program z 1980 r. okazał się całkowicie anachroniczny w latach 90. szczególnie po wejściu Zielonych do rządu. Stanowil kompromis między wieloma nurtami, z których powstała partia i w wyraźny sposób przedstawiał ich cele. \a różnorodność sprawiła, że programowi brakowało porządku, spójności i pewnej logiki. Był on listą życzeń zawierającą różnorodne, nierzadko sprzeczne dążenia Odejście najbardziej radykalnych inicjatyw, doświadczenia $z$ udziału w rządach krajowych a także wiele innych czynników jak choćby nasilające się procesy globalizacyjne, wskazywało na konieczność nowego zdefiniowania celów

W marcu 2002 na zjeździe w Berlinie zatwierdzono nowy program „Przyszłość jest zielona" ${ }^{\text {"31 }}$. W nowym programie swoje odzwierciedlenie znalazło doświadczenie współrządzenia krajem przez czas jednej kadencji. Uwidacznia się to w dążeniu Zielonych do zerwania z promowanym kiedyś, wizerunkiem partii „antypartyjnej” i chęci ukształtowania obrazu alternatywy w systemie partyjnym zdolnej do przeprowadzenia reform. Zmieniła się retoryka, natychmiastowe żądania zastąpiono

29 Por. P. 囚Iefenbach, Die Grünen. Verstaatlichung einer Partei, Kolonia, 1998, s. 61-68.

30 Por. M. Klein, J. Falter, Der lange..., op. cit., s. 76-78

31 Projekt programu: www.gruene.de. 
metodą „małych kroków” w celu realizacji „zielonych idei”. Jako drogowskaz dzialań wybrano cztery zasady lączące tradycje lewicowe z liberalnymi: ekologia, samookreślenie, sprawiedliwość, demokracja. W ten sposób z pierwszego programu na pierwszorzędnym miejscu pozostała ekologia, natomiast pozostałe wartości zostały zdefiniowane na nowo ${ }^{32}$.

Centralne znaczenie w nowym programie przybiera pojęcie równowagi, które odnosi się nie tylko do prowadzenia polityki ekologicznej w oparciu o zasadę zrównoważonego rozwoju, ale dotyczy także innych obszarów jak gospodarka, finanse czy polityka socjalna ${ }^{33}$. Ochrona środowiska ma być realizowana przez wspieranie alternatywnych środków energii, rozwijanie nowoczesnych technologii oraz wspieranie oszczędnych systemów produkcji. Cały rozdział programu zatytułowano „Wymarsz w ekologiczną społeczną gospodarkę rynkową". Zieloni przeszli w tym zakresie swoje poglądy o 180 stopni względem pierwszego programu uznając, że problemy ekologiczne są rozwiązywalne w ramach wolnego rynku. Zieloni stwierdzili, że umożliwia to wprowadzenie przejrzystego systemu podatkowego z podatkiem ekologicznym w równym stopniu obciążającym konsumentów i producentów. Wyrażono także przekonanie, że rozwój ekologicznych technologii przyszłości pozwoli na stworzenie dużej ilości nowych miejsc pracy ${ }^{34}$.

Sprawiedliwość przestała być pojmowana w rozumieniu sprawiedliwego podziału środków, ale została rozszerzona na sprawiedliwość międzypokoleniową, międzypłciową i międzynarodową. W sprawiedliwości widzą Zieloni odpowiedź na problemy, z którymi zmaga się podlegający gwałtownym przemianom świat. 冈akże w pojmowaniu demokracji Zieloni odeszli od prób wprowadzenia demokracji bezpośredniej kładąc nacisk na reformę instytucji demokracji pośredniej oraz wzmocnienie zaangażowania społeczeństwa obywatelskiego. Najbardziej rewolucyjne zmiany zaszły w temacie wolności od przemocy, gdyż Zieloni uznali wojnę jako ostateczny środek uniknięcia ludobójstwa ${ }^{35}$.

Oprócz czterech wartości podstawowych sprecyzowano cele polityczne w dwunastu projektach kluczowych: wiek energii słonecznej, ekologiczna mobilność, nowe rolnictwo, niemiecka przyszłość, przejrzystość dla konsumentów, dostęp do wiedzy jako prawo obywatelskie, sprawiedliwy handel i międzynarodowe standardy, polityka przyjazna dzieciom, Europa obywateli, społeczeństwo imigrantów, polityka kobieca.

32 Por. A. Mirska, Sojusz 90/Zieloni w: K. A. Wojtaszczyk (red.), Parie polityczne w Niemczech, Warszawa 2004, s. 142.

33 Por. M. KLein, J. Falter, Der lange Weg..., op. cit., s. 81.

34 Por. ibidem, s. 83.

35 Por. A. Mirska, Sojusz 90/Zieloni..., op. cit., s. 143. 
Podsumowując najważniejsze różnice między programami w pierwszym rzędzie należy wymienić zmianę natychmiastowych żądań i przedstawiania rzeczywistości $w$ dramatyczny sposób na stopniowe osiąganie podstawowych celów wymagających dobrego przygotowania. Program z 2002 r. nacechowany jest optymizmem i realizmem, nie zawiera tak wielu prowokacyjnych propozycji, odzwierciedla tym samym doświadczenia rządowe. W porównaniu z pierwszym programem nie jest kompromisem kilku ideologii, co nadaje wewnętrzną spójność, której brakowało poprzednikowi. Myślą przewodnią, znakiem pewnej kontynuacji jest ochrona środowiska wraz z zasadą zrównoważonego rozwoju. Znamienne w porównaniu z umową zjednoczeniową z $1993 \mathrm{r}$. jest przesunięcie na dalszy plan zasady praw człowieka, będącej priorytetem dla partnerów z Sojuszu 90. Uwidacznia się tym samym dominacja spraw najważniejszych dla Zielonych z landów zachodnich, które przy powstaniu partii na wschodzie nie odgrywały żadnej roli. Đym samym utwierdził się pogląd, że Zieloni są partią zachodnioniemiecką.

Patrząc z perspektywy czasu widać, że obawy przed destabilizacją systemu społeczno-gospodarczo-politycznego Niemiec przez nowy ruch społeczny nie spełniły się. Partia Zielonych przeszła długą drogę od ruchu społecznego przez partię opozycyjną, aż po udział w koalicji rządowej, w której udowodniła, że jest w stanie sprostać trudnym wyzwaniom, jak choćby poparcie uczestnictwa Bundeswehry w misji pokojowej w Kosowie oraz wziąć odpowiedzialność za podejmowane decyzje. Przede wszystkim jednak należy podkreślić ewolucję programową od bardzo radykalnych, prowokacyjnych poglądów na kwestię ekologii, gospodarki i bezpieczeństwa po wyważone, kompleksowe propozycje rozwiązywania problemów. Poważnym problemem Partii Zielonch jest jej słabość w krajach związkowych byłego NRD, gdzie silnie zakorzenione są partie postkomunistyczne i partie neonazistowskie, mające swoje reprezentacje we wschodnich krajach związkowych.

\section{LI冈ERA冈URA}

Bachmann K., Buras P., PŁóciennik S., Republika bez gorsetu, Wrocław 2005.

BELL. D., Kulturowe sprzeczności kapitalizmu, Warszawa 1998.

KarolczaK K, Od chadecji do syjonizmu. Szkice o myśli politycznej XX wieku, Warszawa 1996.

Klein M., Falter J., Der lange Weg der Grünen, Monachium 2003.

Kleinert H, Die Grünen in Deutschland, w: Heinrich-Böll-Stiftung (wyd), Die Grünen in Europa. Ein Handbuch, Münster 2004, s. 58-82

Mirska A., Sojusz 90/Zieloni, w: Wojtaszczyk A. K. (red.), Partie polityczne w Niemczech, Warszawa 2004, s.132-156.

Miziniak W., Zieloni w Republice Federalnej Niemiec, Poznań 1990. 
Müller-Rommel F., Pgunt ke \., Die Grünen, w: Mintzel A., Oberreuter H. (red.), Parteien in der Bundesrepublik Deutschland, Bonn 1992, s. 319-361.

Niclauß K., Das Parteisystem der Bundesrepublik Deutschland, München 1995.

Pį̨сIAK W., Niemcy. Droga do normalności, Warszawa 2000

Rudzio W., Das politische system der Bundesrepublik Deutschland, Opladen 2003.

囚iefenbach P., Die Grïnen. Verstaatlichung einer Partei, Kolonia, 1998.

Wojtaszczyk K. A. (red.), Niemcy po zjednoczeniu, Warszawa 1995.

Veen H. J, Hoffmann J., Die Grünen zu Begin der neunziger Jahre, Bonn 1992.

\section{SUMMARY}

The author presents in this paper the developing process of German Green Party. In the 1970s new social movements like environmentalists, peace organizations and feminist founded political party The Greens (Die Grünen). It was an act of opposition against pollution, use of nuclear power, and some aspects of life in highly developed and industrialized society. The formal inauguration was held 1980 in West Germany. 1990 three civil rights groups in East Germany combined to form Bündnis 90, which merged which merged with Die Grünen after long uniting process in 1993.18 years after foundation they built together with social democrats from SPD government which lasted for two term of office between 1998 and 2005. \oday there are a lot of green parties all over the world, but and the German greens are the most successful. They are an example for other green parties. 